\title{
The burden of unrecognised chronic kidney disease in patients with type 2 diabetes at a county hospital clinic in Kenya: implications to care and need for screening
}

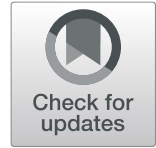

Frederick C. F. Otieno ${ }^{1,2^{*}}$ (D) Elijah N. Ogola ${ }^{1,2}$, M. W. Kimando ${ }^{1,3}$ and Kenn Mutai ${ }^{2}$

\begin{abstract}
Background: Chronic Kidney Disease (CKD) in patients with type 2 diabetes enhances the cardiovascular risk profiles and disease, and is a strong predictor of progression to end-stage kidney disease. Early diagnosis is encouraged for referral to specialist kidney care to initiate active management that would optimize outcomes including forestalling progression to end-stage kidney disease.

This study was conducted in a regional referral public health facility in Central Kenya with a high prevalence of type 2 diabetes. It was aimed at finding out the burden of undiagnosed chronic kidney disease in their clinic of ambulatory patients with type 2 diabetes who dwell mainly in the rural area.

Methods: A cross-sectional study was conducted at the out-patient of Nyeri County hospital. A total of 385 patients were enrolled over 5 months. Informed consent was obtained and clinical evaluation was done, a spot sample of urine obtained for albuminuria and venous blood drawn for HbA1c, Lipids and serum creatinine. Estimated GFR (eGFR) was calculated using the Cockroft-Gault equation. Chronic kidney disease (CKD) was classified on KDIGO scale. Albuminuria was reported as either positive or negative. Descriptive statistics for data summary and regression analysis were employed on SPSS V23.
\end{abstract}

Results: A total of 385 participants were included in the study, 252 (65.5\%) were females. There were 39.0\% (95\%Cl 34.3-44.2) patients in CKD/KDIGO stages 3, 4 and 5 and 32.7\% (95\% Cl, 27.8-37.4) had Albuminuria. The risk factors that were significantly associated with chronic kidney disease/KDIGO stages 3, 4 and 5 were: age $>50$ years, long duration with diabetes $>5$ years and hypertension. Employment and paradoxically, obesity reduced the odds of having CKD, probably as markers of better socio-economic status.

Conclusion: Unrecognized CKD of KDIGO stages 3,4 and 5 occurred in over $30 \%$ of the study patients. The risk factors of hypertension, age above 50 , long duration of diabetes should help identify those at high risk of developing CKD, for screening and linkage to care. They are at high risk of progression to end-stage kidney disease and cardiovascular events. The imperative of screening for chronic kidney disease is availing care in publicly-funded hospitals.

\footnotetext{
* Correspondence: cfotieno@gmail.com

${ }^{1}$ Department of Clinical Medicine and Therapeutics, College of Health

Sciences, University of Nairobi, Box 19676-00202, Nairobi, Kenya

2Division of Medicine, Kenyatta National Hospital, Box 20723-00202, Nairobi,

Kenya

Full list of author information is available at the end of the article
}

(c) The Author(s). 2020 Open Access This article is distributed under the terms of the Creative Commons Attribution 4.0 International License (http://creativecommons.org/licenses/by/4.0/), which permits unrestricted use, distribution, and reproduction in any medium, provided you give appropriate credit to the original author(s) and the source, provide a link to the Creative Commons license, and indicate if changes were made. The Creative Commons Public Domain Dedication waiver (http://creativecommons.org/publicdomain/zero/1.0/) applies to the data made available in this article, unless otherwise stated. 


\section{Background}

Approximately $40 \%$ of patients with diabetes, in their lifetime, develop Diabetes Kidney Disease defined by impaired or falling Glomerular Filtration Rate and/or albuminuria [1]. Additional development of CKD on diabetes greatly enhances the risk of cardiovascular events and poor cardiovascular outcomes [2-5].

.The UKPDS [6] demonstrated that after median follow up of 15 years, $38 \%$ of the study patients previously with normo-albuminuria and 29\% normal GFR developed albuminuria and impaired GFR respectively. The time span to kidney events may certainly be shorter in real-life and non-trial clinical care conditions, probably more so in sub-Saharan Africa where the challenges to organization and provision of care limit achievement of optimal care for so many patients.

CKD in type 2 diabetes is a subtle disease in early phases, but when it becomes manifest, it is severe. Patients seek care when prompted by symptoms. However, access to care is considered insufficient until those at high risk of developing CKD are screened and case identification established as a standard of care.

That CKD is defined by albuminuria and/or impaired eGFR is important because they are relatively easy to measure though not routinely done or reported. In Kenya, indeed in sub-Saharan Africa, early and timely case-finding and access to care are challenges occasioned by scarce resources and non-integrated healthcare systems which can still be overcome. End-stage kidney disease is much worse: it is costly [7, 8] and carries high mortality [9], therefore secondary prevention strategies should be strengthened.

The context of the study is that public hospitals have challenges of healthcare provision at the level of clinical staff and the care support within the facilities, especially laboratories and pharmacies. Therefore, it is presumable that secondary prevention is sub-optimal in the patients who use such facilities.

\section{Methods}

\section{Study design}

A cross-sectional analysis of adult patients with type 2 diabetes without overt complications or co-morbidities attending the out-patient diabetic clinic.

\section{Sample size determination}

A minimum sample size of 295 was determined using Fischer's formula, $N=1 / \mathrm{d}^{2} *\left(\mathrm{Z}^{2} \times \mathrm{P}(1-\mathrm{P})\right), N=$ Sample size, $Z=1.96$ (95\% confidence interval), $P=$ Estimated proportion of chronic kidney disease in type 2 diabetes patients $=26 \%$ [from a previous study [10],], $d=$ Margin of error (precision error) $= \pm 5 \%$, substituting into the formula, $N=295$. However, we enrolled 385 participants to address the objective of adequacy of control of cardiovascular risk factors in the same target population, already published [11].

\section{.Study setting}

The study site is a public hospital in Central Kenya, a region of higher prevalence of type 2 diabetes. The diabetes clinic is run every Friday morning each week except on public holidays. About 100 patients with either type 1 or 2 diabetes mellitus are seen on each clinic day by a Medical officer, registered Nursing staff and occasionally, a consultant physician. Booked patients receive clinical reviews that include but not limited to, weight and Blood Pressure measurements, diabetes education and blood glucose assays. Serum lipids, creatinine, and Albuminuria tests are not routine for patients on a clinic day.

\section{Study population}

Adults with file diagnosis of type 2 diabetes, aged $>30$ years, on follow-up in the clinic for not less than 6 months and on anti-diabetic treatment.

\section{Exclusion criteria}

We excluded patients who were/had type 1 diabetes mellitus or type 2 diabetes that had been hospitalized in the previous 1 month prior to the index clinic visit, file diagnosis of heart failure or chronic kidney disease, secondary diabetes mellitus. Those patients with type 2 diabetes who declined to give consent to participate were also excluded.

They were enrolled on consecutive clinic days over nearly five (5) months between November, 2014 and early March 2015.

\section{Sampling, recruitment and data collection}

The investigators went through the files before the start of the day's clinic session and selected all eligible patients. The eligible participants, on each morning of the clinic day, were assigned random numbers and then systematically selected. Each patient who met the inclusion criteria was given full explanation of the study and enrolled after giving written informed consent. Summary of the recruitment flow is shown on Fig. 1.

Figure 1 summarizes the recruitment flow of the study subjects. Three hundred and eighty-five (385) patients with type 2 diabetes in ambulatory setting were included in the study.

We documented socio-demographic information of age, gender, occupation, level of education, duration of diabetes, and treatment history (of hyperglycaemia, hypertension, and lipid disorder) and any other illnesses. Chart/file review was done to corroborate the information. HIV status was enquired and all the patients interviewed reported a negative status. Marital status, level of 


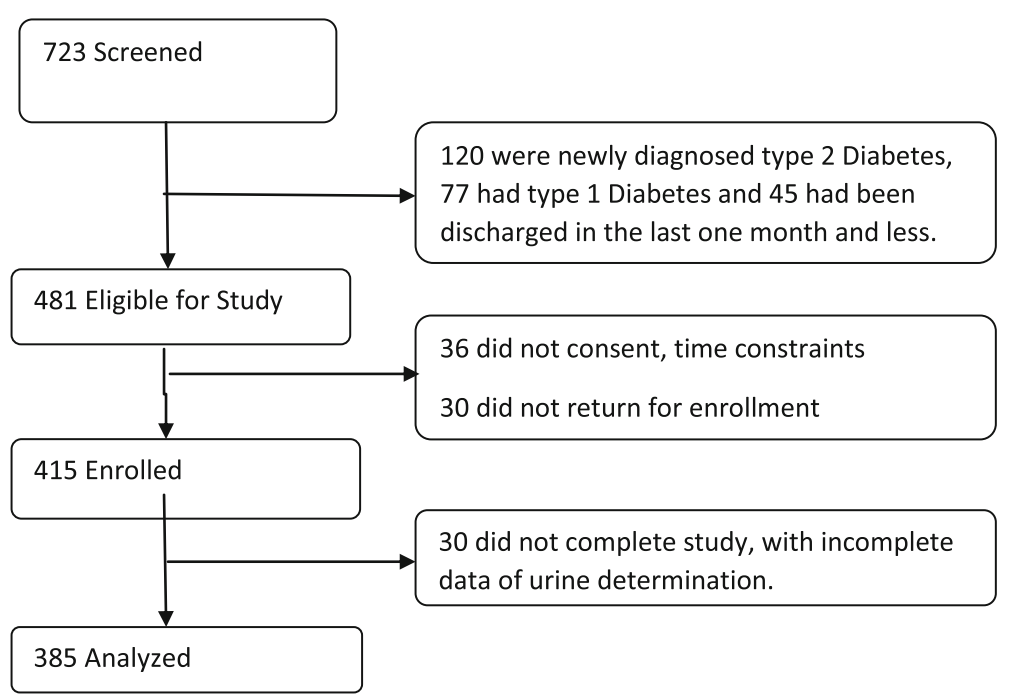

Fig. 1 A flow chart of recruitment and enrolment of subjects into the study

formal education, alcohol intake and cigarette smoking were recorded.

Full clinical examination was done; weight and height were measured and BMI calculated as Weight $(\mathrm{kg})$ divided by square of Height $\left(\mathrm{m}^{2}\right)$. Waist and hip circumferences were also measured in centimeters. Blood Pressure was determined using a manual mercury sphygmomanometer, the standard way, after the patient had rested for not less than ten (10) minutes. Diagnosis of hypertension was made at $\mathrm{BP} \geq 140 / 90 \mathrm{mmHg}$, and classified per JNC 8 [12].

\section{Laboratory}

A $10-\mathrm{ml}$ venous blood sample was drawn from the antecubital fossa, from which a 2-ml blood sample was processed in an EDTA-anti-coagulated bottle for $\mathrm{HbA}_{1} \mathrm{c}$ determination. HBA1c was processed by glycolhemoglobin ion exchange resin method from $E R B A$ MANNHEIM Gmbh at the laboratory. Any value of HbA1c $>7.0 \%$ was considered sub-optimal control. The other $8-\mathrm{ml}$ blood sample was processed in a plane bottle and transported for automated assay of serum creatinine and lipids.

Lipid profile was analyzed using Human Gmbh kit. Total cholesterol was measured using the CHOD-PAP method based on Trinders Methodology, a calorimetric, enzymatic test for cholesterol with lipid clearing factor. HDL cholesterol was measured using human cholesterol liqui-color Phosphatungstic Acid method, end-point kit. GPO-PAPA METHOD, a colorimetric, enzymatic method with glycerophosphate oxidase was employed to assay the triglycerides. LDL-cholesterol was computed from the formula: $[\mathrm{LDL}-\mathrm{chol}]=[$ Total chol $]-[\mathrm{HDL}-$ chol] - ([TG]/2.2) where all concentrations are given in $\mathrm{mmol} / \mathrm{L}$. LDL-Cholesterol above $2.0 \mathrm{mmol} / \mathrm{L}$ was considered higher risk level.

From the serum creatinine results, estimated glomerular filtration rate was calculated on Cockroft-Gault formula:

$$
\text { GFR-Cockcroft-Gault }=\frac{(140-\text { age } \times \text { body weight })}{\text { serum creatinine } \times 0.814 \text { for males }}
$$

The results were the multiplied by 0.85 for females; where age is in years, weight in $\mathrm{kg}$ and serum creatinine in micromol/L. [13].

SPOT urine was obtained from each participant in the morning of the clinic day for Albuminuria determination semi-quantitatively as Urinary albumin to creatinine ratio. CLINITEK Microalbuminuria reagent strips were used, where CLINITEK Micral-2 Strips were dipped in freshly-voided urine sample to provide semi-quantitative albumin-to-creatinine ratio results in 1 minute.

A single spot urine test has been demonstrated as reliable [14], and has been shown to compare well with the gold standard, 24-h urinary albuminuria [15].

\section{Statistical analysis}

We then summarized the data and categorical data (gender, age categories, socio-demographics, habits of alcohol-intake, cigarette-smoking and other clinicolaboratory categories-especially eGFR categories/stages) were summarized as proportions. The continuous data were presented as mean $(+/-\mathrm{SD})$, median and interquartile range. Differences in mean $+/-\mathrm{SD}$ between the 
socio-demographic and clinical characteristics of the patient groups were analyzed using student t-tests. Chisquare and odds ratios (OR), where applicable, were used for association of variables with chronic kidney disease. Logistic regressions were done on bivariate analysis where/when $p$-value was significant, $p<0.05$. The odds ratios (OR) were expressed in $95 \%$ confidence intervals and $\mathrm{p}$-value was taken as significant at $p \leq 0.05$. These were analyzed on the statistical software, SPSS version 20.0.

\section{Results}

A total of 385 participants were included in the study, $252(65.5 \%)$ were females.

The characteristics of the study population are summarized in the Table 1 below.

Table 1 shows socio-demographic and treatment information of the study subjects. The population mean age was 63.3 years, IQR of 56-71 years. The males were significantly older, 65.7(13.7) years than the females, 62.1(12.0) years. The proportion of females with obesity $\left(B M I \geq 30 \mathrm{~kg} / \mathrm{m}^{2}\right)$ was $26.2 \%$, compared to males at $15.0 \%$, and similarly, more females than males had obesity when waist circumference was used. The bold $p$ values depict statistically significant differences between males and females.

Two hundred and thirty-three, $60.5 \%$ of the study subjects had poor glycaemic control and 191 (49.6\%) had hypertension, of whom more than $75.0 \%$ of them were poorly controlled. The proportion of males and females with optimal control of hypertension and glycaemia were similar. However, the lipid parameters of total cholesterol and LDL-cholesterol were higher and HDLcholesterol lower in the females.

The proportions of the study subjects with CKD in the various KDIGO stages (by eGFR) were: G1 $(>90 \mathrm{ml} /$ $\left.\mathrm{min} / 1.73 \mathrm{~m}^{2}\right)-20 \%$, G2 $\left(60-90 \mathrm{ml} / \mathrm{min} / 1.73 \mathrm{~m}^{2}\right)-41 \%$, G3a $\left(45-60 \mathrm{ml} / \mathrm{min} / 1.73 \mathrm{~m}^{2}\right)-21 \%$ and G3b $(30-45 \mathrm{ml} /$ $\left.\min / 1.73 \mathrm{~m}^{2}\right)-12.5 \%$, G4 $\left(15-30 \mathrm{ml} / \mathrm{min} / 1.73 \mathrm{~m}^{2}\right)-4.7 \%$, and $\mathbf{G 5}\left(<15 \mathrm{ml} / \mathrm{min} / 1.73 \mathrm{~m}^{2}\right)-0.8 \%$. One hundred and fifty, $39.0 \%$ of the study patients had eGFR $<60 \mathrm{ml} / \mathrm{min} /$ $1.73 \mathrm{~m}^{2}$ while one hundred and twenty-six, $32.7 \%$ of them had Albuminuria. There were no gender differences in the proportions of subjects with albuminuria and those in the various CKD/KDIGO stages.

Table 2 shows treatment choices of the study patients: Over two-thirds, 68.1\%, were on oral agentsonly and $29.1 \%$ were on insulin-based therapy, either as combination with oral agents $(12.0 \%)$ or insulinonly (17.1\%). Use of ACEi/ARBs for hypertension treatment was documented in $69.0 \%$. Over $80 \%$ of the subjects made four or more clinic visits in the previous 12 months.
Table 3 shows bivariate analysis of subjects in the early Chronic Kidney Disease (CKD) stages 1 and 2 compared to those with advanced CKD stages 3, 4 and 5. The mean age of the patients with advanced Chronic Kidney Disease $\left(\mathrm{eGFR}<60 \mathrm{ml} / \mathbf{m i n} / \mathbf{1 . 7 3 m ^ { 2 }}\right)$ was 70.8 years compared with 58.6 years of those in early CKD stages 1 and 2. The subjects in early CKD stages 1 and 2 had markers of better socio-economic status (namely, higher level of formal education and employment) than their counterparts with advanced CKD stages 3, 4 and 5. The mean SBP was higher (148.8 $\mathrm{mmHg}$ vs. $140.3 \mathrm{mmHg}$ ), and duration of diabetes was longer (11.0 versus 5.0 years) in patients with advanced CKD/KDIGO stages 3,4 and 5 compared to those in early CKD/KDIGO stages 1 and 2. Gender did not increase the odds of occurrence of advanced CKD stages 3,4 and 5 , as the proportions were not significantly different between females (36.9\%) and the males (42.9\%), $(p>0.05)$.

The patients in either of the CKD groups had similar glycaemic control and mean diastolic blood pressure. Obesity $\left(\mathrm{BMI} \geq 30 \mathrm{~kg} / \mathrm{m}^{2}\right)$ paradoxically reduced the odds of having advanced CKD (eGFR $<60 \mathrm{ml} / \mathrm{min} /$ $\left.1.73 \mathrm{~m}^{2}\right)$.

Table 4 shows logistic regression of the risk factors of higher stages of CKD (eGFR $\left.<60 \mathrm{ml} / \mathrm{min} / 1.73 \mathrm{~m}^{2}\right)$ and their adjusted Odds Ratios (OR) that were significant at bivariate analysis. Age above 50 years, longer duration of diabetes $>5$ years, systolic blood pressure $\geq 140 \mathrm{mmHg}$ and obesity $\left(\mathrm{BMI} \geq 30 \mathrm{~kg} / \mathrm{m}^{2}\right.$ ) were significant determinants of Chronic Kidney Disease (eGFR $<60 \mathrm{ml} / \mathrm{min} /$ $\left.1.73 \mathrm{~m}^{2}\right)$.

Age, marital status, level of formal education, employment status, duration of diabetes in years, obesity of BMI $\geq 30 \mathrm{~kg} / \mathrm{m}^{2}$ and hypertension were included in the logistic regression model. Age, duration of diabetes above 5 years, hypertension (as both continuous and categorical variables) were found to increase the odds of having CKD/KDIGO stages 3 to 5 , but obesity (by BMI) mitigated the risk of having Chronic Kidney Disease in the study patients.

Table 5 shows risk factor loading and the change in the odds of having advanced stages of Chronic Kidney Disease $\left(e G F R<60 \mathrm{ml} / \mathrm{min} / 1.73 \mathrm{~m}^{2}\right)$. Hypertension alone increased the odds by three times $(\times 3)$, but addition of glycaemic control (HbA1c), age above 50 years, duration of diabetes $>5$ years and cigarette-smoking increased the odds by six times $(\times 6)$.

Abbreviations. CKD - Chronic Kidney Disease, KDIGO - Kidney Disease. Improving Global Outcomes. ACEi/ ARBs- Angiotensin Converting Enzyme inhibitors/Angiotensin Receptor Blockers.

Figure 2 depicts a pie-chart representing the prevalence of albuminuria amongst the study patients. 
Table 1 Clinical and laboratory characteristics by gender of the study patients

\begin{tabular}{|c|c|c|c|c|c|}
\hline Variable & $\begin{array}{l}\text { Overall }(N=385) \\
N(\%)\end{array}$ & $\begin{array}{l}\text { Female }(N=252) \\
N(\%)\end{array}$ & $\begin{array}{l}\text { Male }(N=133) \\
N(\%)\end{array}$ & OR $(95 \% \mathrm{Cl})$ & $P$ value \\
\hline Age, years, mean(SD) & 63.3 & $62.1(12.0)$ & $65.7(13.7)$ & - & 0.006 \\
\hline $\begin{array}{l}\text { BMl,kg/m², mean (SD) } \\
\text { Categories, n (\%) }\end{array}$ & $26.7(4.6)$ & & & & \\
\hline Underweight- $(<18.5$ kg/m²) & $6(1.6)$ & $4(1.6)$ & $2(1.5)$ & $1.5(0.3-8.3)$ & 0.660 \\
\hline Normal- $\left(18.5-25 \mathrm{~kg} / \mathrm{m}^{2}\right)$ & $139(36.1)$ & $80(31.7)$ & $59(44.4)$ & 1.0 & - \\
\hline Overweight- $(25-29.9$ kg/m²) & $154(40.0)$ & $102(40.5)$ & $52(39.1)$ & $1.4(0.9-2.3)$ & 0.127 \\
\hline Obese- $\left(\geq 30 \mathrm{~kg} / \mathrm{m}^{2}\right)$ & $86(22.3)$ & $66(26.2)$ & $20(15.0)$ & $2.4(1.3-4.4)$ & 0.004 \\
\hline $\begin{array}{l}\text { Waist Circumference, cm, mean (SD) } \\
\text { Categories, n (\%) }\end{array}$ & $92.5(22.0)$ & & & & \\
\hline Undesirable, $>102 \mathrm{~cm}(\mathrm{M}) />88 \mathrm{~cm}(\mathrm{~F})$ & $224(58.2)$ & $171(67.9)$ & $53(39.8)$ & $3.2(2.1-4.9)$ & $<0.001$ \\
\hline Normal & $161(41.8)$ & $81(32.1)$ & $80(60.2)$ & 1.0 & \\
\hline \multicolumn{6}{|l|}{ Hypertension, BP > 140/90 mmHg } \\
\hline Hypertensive, n (\%) & $191(49.6)$ & $196(77.8)$ & $99(74.4)$ & $1.2(0.7-2.0)$ & 0.461 \\
\hline Normal BP & $194(50.4)$ & $56(22.2)$ & $34(25.6)$ & 1.0 & \\
\hline \multicolumn{6}{|l|}{ Glycemic control, HbA1c (\%) } \\
\hline Glycaemia, HbA1c \%, mean(SD) & $8.1(2.8)$ & $8.3(3.0)$ & $7.9(2.7)$ & - & 0.181 \\
\hline Poor control, $\mathrm{HbA} 1 \mathrm{c}>7.0$ & $233(60.5)$ & $154(61.1)$ & $79(59.4)$ & $1.1(0.7-1.6)$ & 0.744 \\
\hline Optimal control, $\mathrm{HbA} 1 \mathrm{c} \leq 7.0$ & $152(39.5)$ & $98(38.9)$ & $54(40.6)$ & 1.0 & \\
\hline $\begin{array}{l}\text { Total cholesterol, mean (SD), mmol/L } \\
\text { Categories, n (\%) }\end{array}$ & $4.6(1.2)$ & $4.9(1.2)$ & $4.2(1.1)$ & - & $<0.001$ \\
\hline High> 4.120 & $88(22.9)$ & $69(27.4)$ & 19 (14.3) & $2.3(1.3-4.0)$ & 0.004 \\
\hline Optimal $\leq 4.120$ & $297(77.1)$ & $183(72.6)$ & $114(85.7)$ & 1.0 & \\
\hline $\begin{array}{l}\text { HDL-cholesterol, mean (SD), mmol/L } \\
\text { Categories, n (\%) }\end{array}$ & $1.3(0.9)$ & $1.4(0.3)$ & $1.3(1.5)$ & - & 0.719 \\
\hline Low $\leq 1.0$ & $80(20.8)$ & $39(15.5)$ & $41(30.8)$ & $0.4(0.2-0.7)$ & $<0.001$ \\
\hline Optimal> 1.0 & $305(79.2)$ & $213(84.5)$ & $92(69.2)$ & 1.0 & \\
\hline $\begin{array}{l}\text { Triglycerides, mean (SD), mmol/L } \\
\text { Categories, } \mathrm{n}(\%)\end{array}$ & $1.7(1.0)$ & $1.7(1.0)$ & $1.7(1.1)$ & - & 0.873 \\
\hline High $>1.7$ & $210(54.5)$ & $135(53.6)$ & $75(56.4)$ & $0.9(0.6-1.4)$ & 0.597 \\
\hline Optimal $\leq 1.7$ & $175(45.5)$ & $117(46.4)$ & $58(43.6)$ & 1.0 & \\
\hline $\begin{array}{l}\text { LDL-cholesterol, mean(SD, mmol/L } \\
\text { Categories, } \mathrm{n}(\%)\end{array}$ & $2.4(0.9)$ & $2.6(0.9)$ & $2.2(0.9)$ & - & $<0.001$ \\
\hline High $>2.0$ & $297(77.1)$ & $206(81.7)$ & $91(68.4)$ & $2.1(1.3-3.4)$ & 0.003 \\
\hline Optimal $\leq 2.0$ & $88(22.9)$ & $46(18.3)$ & $42(31.6)$ & 1.0 & \\
\hline \multicolumn{6}{|l|}{ CKD/(KDIGO categories) } \\
\hline $\mathrm{G} 1, \mathrm{e} G F R>90 \mathrm{ml} / \mathrm{min} / \mathrm{m}^{2}$ & $77(20.0)$ & $53(21.0)$ & $24(18.0)$ & 1.0 & \\
\hline G2, eGFR 60-90 & $158(41.0)$ & $106(42.1)$ & $52(39.1)$ & $0.9(0.5-1.7)$ & 0.789 \\
\hline G3a eGFR 59-45 & $81(21.0)$ & $48(19.0)$ & $33(24.8)$ & $0.7(0.3-1.3)$ & 0.211 \\
\hline G3b eGFR 44-30 & $48(12.5)$ & $30(11.9)$ & $18(13.5)$ & $0.8(0.4-1.6)$ & 0.467 \\
\hline G4 eGFR 29-15 & $18(4.7)$ & $13(5.2)$ & $5(3.8)$ & $1.2(0.4-3.7)$ & 0.779 \\
\hline G5 eGFR $<15$ & $3(0.8)$ & $2(0.8)$ & $1(0.8)$ & $0.9(0.1-10.5)$ & 0.937 \\
\hline \multicolumn{6}{|l|}{ Albuminuria status } \\
\hline Albuminuria present & $126(32.7)$ & $80(31.7)$ & $46(34.6)$ & $0.9(0.6-1.4)$ & 0.572 \\
\hline NO Albuminuria & $259(67.3)$ & $172(68.3)$ & $87(65.4)$ & 1.0 & \\
\hline
\end{tabular}


Table 2 Treatment Information of the study patients

\begin{tabular}{ll}
\hline Variable & Proportion, N (\%) \\
\hline Diabetes mellitus treatment & $11(2.9)$ \\
Diet-only & $262(68.1)$ \\
Oral Glucose-lowering Agents(OGLAs)-only & $66(17.1)$ \\
Insulin-only & $46(12.0)$ \\
Insulin combined with Oral Glucose-lowering Agents & 45 (11.7) \\
Other co-medications used regularly by the subjects & 48 (12.5) \\
Anti-platelets & 108 (28.1) \\
Statins & 295 (76.6) \\
Anti-platelets and statins & 204 (69.0) \\
Anti-hypertensive drugs & 68 (17.7) \\
- ACEi/ARBs & $292(75.9)$ \\
Frequency of clinic attendance in the last 12 months & 25 (6.5) \\
4-3 -5 &
\end{tabular}

ACEi Angiotensin Converting Enzyme inhibitors, ARBs Angiotensin Receptor Blockers

Figure 3 is a bar chart showing the proportion of the study patients in the various of KDIGO stages of chronic kidney disease.

\section{Discussion}

The prevalence of CKD stages 3 to 5 in this adult population who were $30 \mathrm{yrs}$. and above, with type 2 diabetes, was $39.0 \%(95 \% \mathrm{CI}, 34.3-44.2)$ by eGFR $(<60 \mathrm{ml} / \mathrm{min} /$ $\left.1.73 \mathrm{~m}^{2}\right)$ and $32.7 \%(95 \% \mathrm{CI}, 32.7-37.4)$ for albuminuria. Focusing on each CKD-stage, $33.5 \%$ were in stage-3, $4.7 \%$ in stage- 4 and $0.8 \%$ in stage- 5 in this study. The occurrence of CKD was previously unknown to both the patients and healthcare providers. These stages of CKD are often asymptomatic, so patients do not promptly seek care. The stages are only detected when appropriate tests are done.

The policy of cost-sharing in public health facilities may have limited access to both clinical care and laboratory diagnostic services of the patients who could not afford them. This study excluded any patients who had recently been discharged from hospital; therefore, the prevalence reported is an underestimate.

The meta-analysis of studies on diabetes kidney disease in sub-Saharan Africa by Noubiap JJ et al. [16] gave a summary on methods used and characteristics of the patients involved in those studies, mentioning some shortcomings that limited adequate comparability. Several of those studies included patients with type 1 and 2 diabetes, conditions with fairly divergent time paths towards evolution of kidney disease, even when risk factors may be common.
In this study, we discuss the prevalence CKD stages 3 to 5 in context of its magnitude, clinical significance, opportunities of case-finding and implication to care needs.

Studies to determine the prevalence of CKD stages 3 to 5 and/or albuminuria in patients with type 2 diabetes in sub-Saharan Africa have found a wide range of figures. Our own study on patients with type 2 diabetes for less than 2 years but relatively younger, in a tertiary hospital, found $26 \%$ had albuminuria [10]. Ngassa et al., in S. Africa found $33.6 \%$ of their patients had proteinuria and $17.3 \%$ had CKD of stages 3, 4 and 5 (eGFR< $60 \mathrm{ml} /$ minute $/ 1.73 \mathrm{~m}^{2}$ ), aggregated for both type 1 and 2 diabetes [17]. The prevalence of CKD in patients with type 2 diabetes was $41.1 \%$ in a Nigerian study [18]. Advanced CKD, of eGFR $<60 \mathrm{ml} / \mathrm{min} / 1.73 \mathrm{~m}^{2}$, was found in 18.2 and $23.8 \%$ of subjects with diabetes using the MDRD and Cockcroft-Gault (C-G) equations respectively, in an Ethiopian study [19], demonstrating that the equation used to calculate eGFR may also explain variations in prevalence. Two studies on patients with type 1 and type 2 diabetes were conducted in two different places in Tanzania: Janmohamed et al., found $79.9 \%$ had albuminuria and $83.7 \%$ had CKD $\left(\right.$ eGFR $<60 \mathrm{ml} /$ minute $\left./ 1.73 \mathrm{~m}^{2}\right)$ [20], while in Lutale et al., $17 \%$ had albuminuria and $22 \%$ had CKD stages 3 to 5 [21]. Their methods of determining proteinuria were different and target populations varied in ages, duration of diabetes and other characteristics. The prevalence of CKD in studies in subSaharan Africa is relatively high, in spite of the differences in patient characteristics within diabetes and the methods used to determine the eGFR. However, CKD and albuminuria still exhibit common determinants of 
Table 3 Bivariate analysis of factors associated with chronic kidney disease in the study subjects

\begin{tabular}{|c|c|c|c|c|}
\hline \multirow[t]{2}{*}{ Variable } & \multicolumn{2}{|c|}{ Chronic Kidney Disease, CKD /KDIGO classification } & \multirow[t]{2}{*}{ OR $(95 \% \mathrm{Cl})$} & \multirow[t]{2}{*}{$P$ value } \\
\hline & Stage $3-5$ & Stage 1-2 & & \\
\hline Age, mean (SD), years & $70.8(8.8)$ & $58.6(11.5)$ & - & $<0.001$ \\
\hline \multicolumn{5}{|l|}{ Age category, years } \\
\hline$\leq 50$ & $0(0.0 \%)$ & $54(100.0 \%)$ & - & $<0.001$ \\
\hline$>50$ & $150(45.3 \%)$ & $181(54.7 \%)$ & & \\
\hline \multicolumn{5}{|l|}{ Gender } \\
\hline Female & $93(36.9)$ & $159(63.1)$ & $0.8(0.5-1.2)$ & 0.255 \\
\hline Male & $57(42.9)$ & $76(57.1)$ & 1.0 & \\
\hline \multicolumn{5}{|l|}{ Marital status } \\
\hline Single, unmarried & $2(9.1)$ & $20(90.9)$ & 1.0 & \\
\hline Married. & $96(37.2)$ & $162(62.8)$ & $5.9(1.4-25.9)$ & 0.018 \\
\hline Widowed & $52(51.0)$ & $50(49.0)$ & $10.4(2.3-46.8)$ & 0.002 \\
\hline Separated & $0(0.0)$ & $3(100.0)$ & - & 0.999 \\
\hline \multicolumn{5}{|l|}{ Level of formal education } \\
\hline None & $29(56.9)$ & $22(43.1)$ & 1.0 & \\
\hline Primary school(1-7yrs) & $87(38.3)$ & $140(61.7)$ & $0.5(0.3-0.9)$ & 0.017 \\
\hline Secondary school(8-12 yrs) & $26(28.9)$ & $64(71.1)$ & $0.3(0.2-0.6)$ & 0.001 \\
\hline Tertiary, > 12 yrs. in school & $8(47.1)$ & $9(52.9)$ & $0.7(0.2-2.0)$ & 0.483 \\
\hline \multicolumn{5}{|l|}{ Employment status } \\
\hline Unemployed & $56(44.8)$ & $69(55.2)$ & 1.0 & \\
\hline Employed & $3(13.0)$ & $20(87.0)$ & $0.2(0.1-0.7)$ & 0.009 \\
\hline Self-employed & $47(31.5)$ & $102(68.5)$ & $0.6(0.3-0.9)$ & 0.025 \\
\hline Retired & $44(50.0)$ & $44(50.0)$ & $1.2(0.7-2.1)$ & 0.454 \\
\hline \multicolumn{5}{|l|}{ Cigarette smoking } \\
\hline Smoker & $38(41.3 \%)$ & $54(58.7 \%)$ & $1.1(0.7-1.8)$ & 0.597 \\
\hline Non-smoker & $112(38.2 \%)$ & $181(61.8 \%)$ & 1.0 & \\
\hline Duration of diabetes, years, median (IQR) & $11.0(5.0-18.0)$ & $5.0(2.0-11.0)$ & - & $<0.001$ \\
\hline \multicolumn{5}{|l|}{ Duration of disease, categories, years } \\
\hline$>5$ & $105(48.2 \%)$ & $113(51.8 \%)$ & $2.6(1.7-4.1)$ & $<0.001$ \\
\hline$\leq 5$ & $41(26.1 \%)$ & $116(73.9 \%)$ & 1.0 & \\
\hline \multicolumn{5}{|l|}{ LDL-cholesterol, mmol/L } \\
\hline High $>2.0$ & $116(39.1)$ & $181(60.9)$ & $1.0(0.6-1.7)$ & 0.943 \\
\hline Normal $\leq 2.0$ & $34(38.6)$ & $54(61.4)$ & 1.0 & \\
\hline \multicolumn{5}{|l|}{ Obesity } \\
\hline Obese, $\mathrm{BMI} \geq 30 \mathrm{~kg} / \mathrm{m}^{2}$ & $17(19.8)$ & 69 (80.2) & $0.3(0.2-0.5)$ & $<0.001$ \\
\hline Not obese, $\mathrm{BMI}<30 \mathrm{~kg} / \mathrm{m}^{2}$ & $133(44.5)$ & $166(55.5)$ & 1.0 & \\
\hline \multicolumn{5}{|l|}{ Hypertension, BP > 140/90 mmHg } \\
\hline Hypertensive & $91(47.6)$ & $100(52.4)$ & $2.1(1.4-3.2)$ & 0.001 \\
\hline Normal BP & $59(30.4)$ & $135(69.6)$ & 1.0 & \\
\hline Systolic BP,mean (SD) mmHg & $148.8(25.6)$ & $140.3(20.6)$ & - & $<0.001$ \\
\hline Diastolic BP, mean (SD) mmHg & $81.9(12.1)$ & $81.2(10.9)$ & - & 0.579 \\
\hline \multicolumn{5}{|l|}{ Glycemic control } \\
\hline Poor (HbA1c > 7.0\%) & $86(36.9)$ & $147(63.1)$ & $0.8(0.5-1.2)$ & 0.307 \\
\hline Good (HbA1c $\leq 7.0 \%)$ & $64(42.1)$ & $88(57.9)$ & 1.0 & \\
\hline
\end{tabular}


Table 4 Logistic regression model of the predictors of Chronic Kidney Disease (CKD) in the study subjects

\begin{tabular}{|c|c|c|c|c|}
\hline \multirow[t]{3}{*}{ Variable } & \multicolumn{3}{|c|}{ Adjusted odds ratios } & \multirow{3}{*}{$\begin{array}{l}p- \\
\text { value }\end{array}$} \\
\hline & \multirow{2}{*}{$\begin{array}{l}\text { Odds } \\
\text { ratio }\end{array}$} & \multicolumn{2}{|c|}{$95 \%$ C.I. } & \\
\hline & & Lower & Upper & \\
\hline Age, above 50 years & 1.12 & 1.09 & 1.16 & $<0.001$ \\
\hline Duration of diabetes (> 5 years) & 1.98 & 1.17 & 3.36 & 0.012 \\
\hline Duration of diabetes, years & 1.05 & 1.05 & 1.08 & 0.005 \\
\hline Obesity, BMI $\geq 30 \mathrm{~kg} / \mathrm{m}^{2}$ & 0.24 & 0.12 & 0.47 & $<0.001$ \\
\hline Systolic blood pressure, SBP $\geq 140 \mathrm{mmHg}$ & 1.014 & 1.003 & 1.025 & 0.012 \\
\hline Hypertension present & 2.3 & 1.2 & 4.5 & 0.015 \\
\hline
\end{tabular}

aging, hypertension, poor glycaemic control and socioeconomic challenges in studies that evaluated them. This study did not show glycaemic control as a significant predictor of chronic kidney disease, likely because of its cross-sectional design.

Screening and case finding for CKD in patients with diabetes is important because early stage disease can be managed to delay progression $[22,23]$.

The potential cost of morbidity and mortality from progressive CKD in type 2 diabetes is enormous, barely affordable in resource-scarce settings. This is much more important in high-risk individuals where the factors that initiate CKD, are often also the drivers of CKD progression.

Renal functions do improve when therapeutic targets are attained [24], therefore CKD and its drivers of progressions should be actively sought for in patients attending general diabetes clinics as standard of care. Modelling of data on screening strategies has demonstrated the cost-effectiveness of screening for CKD and optimally managing hypertension [25].

.Our study showed that age above 50 years, (and age as a continuous variable), was associated with having CKD/
KDIGO stages 3 to 5 . In addition, living with diabetes for 5 years and more, increased the odds of having advanced CKD stages. Similarly, other studies have demonstrated that aging is associated with deteriorating kidney function [26, 27], and long duration of diabetes compounds it [28]. These parameters are easily determined in clinics and should assist in stratifying our patients into risk categories during routine follow-up for casefinding, especially in patients who also have other risk factors like hypertension, chronic poor glycaemic control and cigarette-smoking. Therefore, sophisticated and/or costly tests are not necessary for case-finding of chronic kidney disease in routine care.

Hypertension, a modifiable risk factor increased by 3fold, the odds of having advanced CKD stages in this study. Hypertension causes chronic kidney disease in type 2 diabetes [29-33] and other cardiovascular events like heart failure [34] and stroke [35, 36] but when hypertension is under control in such subjects who retain normal kidney function, it mitigates the potential for developing CKD [37, 38]. Conversely, poor or insufficient control of hypertension initiates CKD (and causes progression of CKD to more advanced stages). Use of ACEi's/ARB's in

Table 5 Logistic regression of risk factors and loading on patients with chronic kidney disease in the study

\begin{tabular}{|c|c|c|c|c|}
\hline Variable & Chronic Kidney Disease (CKD) & Normal, non-CKD & OR $(95 \% \mathrm{Cl})$ & $P$ value \\
\hline \multicolumn{5}{|l|}{ Risk factor loading, } \\
\hline 0-Normal Blood Pressure & $20(22.2 \%)$ & $70(77.8 \%)$ & 1.0 & \\
\hline 1-Hypertension (HTN) & $53(47.3 \%)$ & $59(52.7 \%)$ & $3.1(1.7-5.8)$ & $<0.001^{*}$ \\
\hline $2-\mathrm{HTN}+\mathrm{HbA} 1 \mathrm{c}>7.0 \%$ & $20(42.6 \%)$ & $27(57.4 \%)$ & $2.6(1.2-5.6)$ & $0.014^{*}$ \\
\hline $3-\mathrm{HTN}+\mathrm{HbA} 1 \mathrm{c}+\mathrm{LDL}>2.0 \mathrm{mmol} / \mathrm{L}$ & $0(0.0 \%)$ & $13(100.0 \%)$ & - & 0.999 \\
\hline $4-H T N+A 1 c+L D L+A g e+D u r<5 y r$ & $17(34.7 \%)$ & $32(65.3 \%)$ & $1.9(0.9-4.0)$ & 0.114 \\
\hline $5-\mathrm{HTN}+\mathrm{HbA} 1 \mathrm{c}+\mathrm{LDL}+\mathrm{Age}+\mathrm{Dur} \geq 5 \mathrm{yr}$ & $29(50.9 \%)$ & $28(49.1 \%)$ & $3.6(1.8-7.4)$ & $<0.001^{*}$ \\
\hline $6-\mathrm{HTN}+\mathrm{A} 1 \mathrm{c}+\mathrm{LDL}+$ Age + Dur $>5 \mathrm{yr}+\mathrm{Cig}$ & $11(64.7 \%)$ & $6(35.3 \%)$ & $6.4(2.1-19.5)$ & $0.001 *$ \\
\hline \multicolumn{5}{|l|}{ 7- ACEI/ARB-use } \\
\hline Yes & $111(41.6)$ & $156(58.4)$ & $1.4(0.9-2.3)$ & 0.114 \\
\hline No & $39(33.1)$ & 79 (66.9) & 1.0 & \\
\hline
\end{tabular}




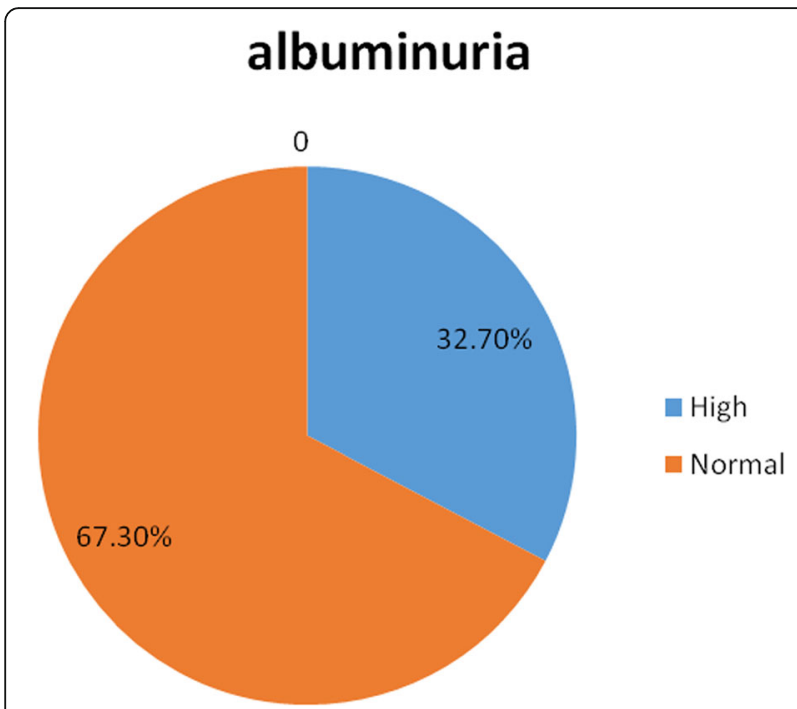

Fig. 2 Albuminuria status of the study subjects. Albuminuria was recorded in $32.7 \%$ of the patients with no significant sex differences; $31.7 \%$ in females and $34.6 \%$ in males $(p=0.572)$

control of hypertension mitigates renal disease progression [39-42]. Our study registered $69.0 \%$ users of ACEi/ ARB agents; however, we did not determine duration of use, doses nor their adherence patterns. Just below a quarter of our study patients with hypertension, at the time of enrolment, had optimal control of the high blood pressure. We have previously documented similar modest proportion of patients with hypertension on type 2 diabetes who achieved optimal Blood Pressure control while on treatment [43]. Another study elsewhere in sub-Saharan Africa [44] also reported similar small proportions, emphasizing that there is urgent need to increase the proportions achieving blood pressure targets.
From this study we infer that diabetes care in the clinic was neither sufficient to achieve optimal control of the modifiable risk factors nor able to detect complications in the patients. These findings suggest that patients with type 2 diabetes for 5 -years and more, aged 50 years and above, have hypertension, also are cigarette-smokers and of modest socio-economic capacity should be screened for CKD. Many patients with type 2 diabetes who attend public hospital clinics in sub-Saharan Africa, may look well, but they will need screening for CKD. The WHO document of Wilson and Jungner [45] supported CKD screening amongst patients with type 2 diabetes because it is a public health problem, that early disease is recognizable and screening tests are acceptable to populations, amongst its 10 items. Indeed, screening for chronic kidney disease in diabetes has been recommended but in the developed world [46-48]. A review from experts to justify the same for overall CKD screen in sub-Saharan Africa was recently published. They noted that screening for a disease would demand availability of (or access to) treatment and that is our major undoing in sub-Saharan Africa $[49,50]$. However, improvement in public health systems should equalize opportunities for access to quality care, in this context, of high-risk diabetic patients like these in our study. The audit part of this study has been published [11]. Spot urine test for albuminuria and occasional kidney function test for eGFR are not often done on these patients, as standard of care. Doing these relatively simple tests unmasked very important clinical information which had been missed out before.

\section{Conclusion}

Screening for CKD and case-finding yielded important information on up to one-third of subjects with type 2 diabetes who were more likely to transit to ESRD or develop cardiovascular events and/or mortality. They

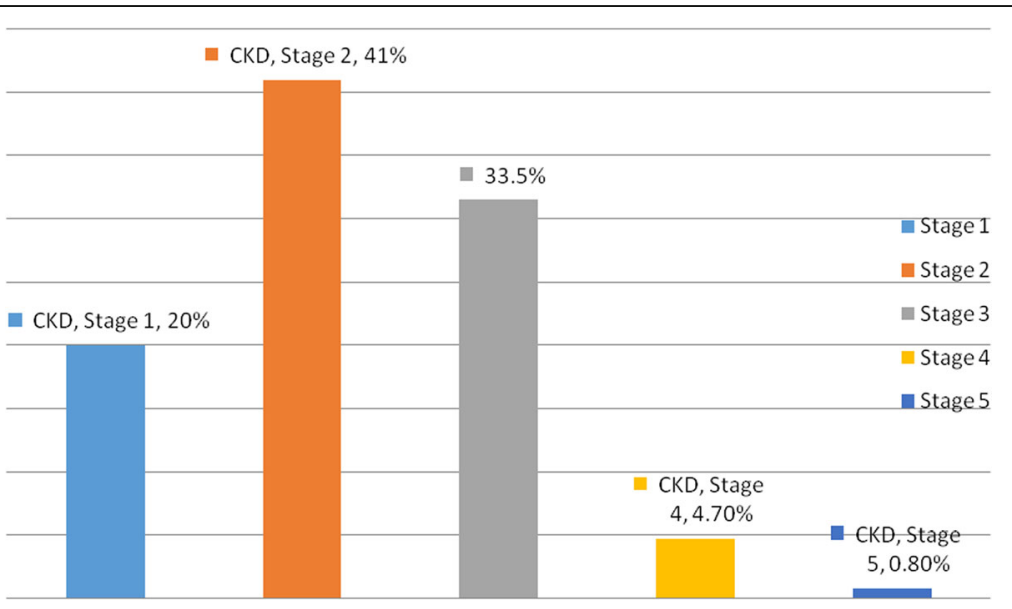

Fig. 3 Chronic Kidney Disease/KDIGO stages and the proportions of study subjects in each stage. There earlier stages 1 and 2 of CKD are moer prevalent than the later ones of stages 3, 4 and 5. This shows that not all stages would progress, and if some m,ay progress, the rates will vary 
needed to be linked to and retained in appropriate care where they are risk-stratified to enhance their level of risk factor control and monitoring.

Therefore, public health systems or hospitals should strive to improve the quality of diabetes care they offer by providing the necessary clinical and laboratory capacities that identify high-risk patients and enabling their care needs.

\section{Acknowledgments}

We are grateful to the academic staff of the Department of Clinical Medicine and Therapeutics who critically reviewed the proposal before the study was conducted. We are also very grateful to the nursing staff at the diabetes outpatient clinic of Nyeri County Hospital who facilitated the study, especially the triaging and recruitment of the study subjects. Gratitude also goes to the laboratory staff for diligent work.

We are indebted to Dorcas, Secretary of the Department of Clinical Medicine and Therapeutics, for sparing time to type and format the final manuscript. Finally, our big gratitude goes to the subjects who voluntarily agreed to participate in the study. We as the authors declare no special or competing interest served by this research and publication.

\section{Authors' contributions}

OCF: design of the study, wrote all the drafts, and the final manuscript. MWK: design of study, data collection, read the drafts, and made inputs in the manuscript. OEN: design of study, read the drafts, and made critical input into the final manuscript. MK: participated in the design, sample size calculation, and statistical analysis. All authors contributed towards data analysis, drafting and critically revising the paper and agree to be accountable for all aspects of the work.

\section{Funding}

Self-funded by CFO and MWK.

\section{Availability of data and materials}

Data and materials are available and can be found in additional file 1.

\section{Ethics approval and consent to participate}

The study was duly approved by the ERC of University of Nairobi/Kenyatta National Hospital and that of Nyeri County Referral Hospital, and this resulting publication was an expectation of the committee. Each participating patient received full explanation of the study and voluntarily gave informed and signed consent to participate, and the results that were obtained informed the care offered.

\section{Consent for publication}

The audit was approved by the Ethical committees of the hospitals and the Department of Clinical Medicine and Therapeutics of the University of Nairobi and one critical requisites of the approval was that the results will published for educational purposes.

\section{Competing interests}

There are none served by this research and publication.

\section{Author details}

${ }^{1}$ Department of Clinical Medicine and Therapeutics, College of Health Sciences, University of Nairobi, Box 19676-00202, Nairobi, Kenya. ${ }^{2}$ Division of Medicine, Kenyatta National Hospital, Box 20723-00202, Nairobi, Kenya. ${ }^{3}$ Nyeri County Hospital, Nyeri, Kenya.

Received: 27 June 2019 Accepted: 27 January 2020

Published online: 28 February 2020

\section{References}

1. National Kidney Foundation. KDOQI clinical practice guideline for diabetes and CKD: 2012 update. Am J Kidney Dis. 2012;60:850-86.

2. Ninomiya T, Perkovic V, de Galan BE, Zoungas S, Pillai A, Jardine M, Patel A, Cass A, Neal B, Poulter N, Mogensen CE, Cooper M, Marre M, Williams B, Hamet P, Mancia G, Woodward M, Macmahon S, Chalmers J, ADVANCE
Collaborative Group. Albuminuria and kidney function independently predict cardiovascular and renal outcomes in diabetes. J Am Soc Nephrol. 2009;20(8):1813-21.

3. Mogensen CE. Micro-albuminuria predicts clinical proteinuria and early mortality in maturity onset diabetes. N Engl J Med. 1984;310:356-60.

4. Valmadrid $C T$, Klein R, Moss SE, Klein BE. The risk of cardiovascular disease mortality associated with micro-albuminuria and gross proteinuria in persons with older-onset diabetes mellitus. Arch Intern Med. 2000;160:1093-100.

5. Sasso FC, Chiodini P, Carbonara O, De Nicola L, Conte G, Salvatore T, Nasti R, Marfella R, Gallo C, Signoriello S, Torella R, Minutolo R. High cardiovascular risk in patients with type 2 diabetic nephropathy: the predictive role of albuminuria and glomerular filtration rate. The NID-2 prospective cohort study. Nephrol Dial Transplant. 2012;27:2269-74.

6. Ravi R, Carole AC, Kerensa IT, Amanda IA, Rury RH. For the UKPDS study group. Risk factorsforrenaldysfunction in type 2 diabetes. UK prospective diabetes study 74. Diabetes. 2006;55:1832-9.

7. Goodkin DA, Bragg-Gresham JL, Koenig KG, Wolfe RA, Akiba T, Andreucci $V E$, Young EW. Association of comorbid conditions and mortality in hemodialysis patients in Europe, Japan, and the United States: the Dialysis outcomes and practice patterns study (DOPPS). J Am Soc Nephrol. 2003; 14(12):3270-7.

8. Vanholder R, Davenport A, Hannedouche T, Kooman J, Kribben A, Lamierre $\mathrm{N}$, et al. Reimbursement of dialysis. A comparison of seven countries. J Am Soc Nephrol. 2012;23:1291-8.

9. Go AS, Chertow CM, Fan D, McCullough CE, Hsu CY. Chronic kidney disease and the risks of death, cardiovascular events, and hospitalization. N Engl J Med. 2004;351:1296-305.

10. Wanjohi FW, Otieno FC, Ogola EN, Amayo EO. Nephropathy in patients with recently diagnosed type 2 diabetes mellitus in black Africans. East Afr Med J. 2002;79:399-404.

11. Kimando MW, Otieno FCF, Ogola EN, Mutai KK. Adequacy of control of cardiovascular risk factors in ambulatory patients with type 2 diabetes attending diabetes out-patients clinic at a county hospital, Kenya. BMC Endocr Disord. 2017;17:73.

12. James PA, Oparil S, Carter BL, Cushman WC, Dennison-Himmelfarb C, Handler J, et al. 2014 evidence-based guideline for the management of high blood pressure in adults: report from the panel members appointed to the Eighth Joint National Committee (JNC 8). JAMA. 2014;311(5):507-20.

13. Rostoker G, Andrivet P, Pham I, Griuncelli M, Adnot S. A modified Cockcroft-Gault formula taking into account the body surface area gives a more accurate estimation of the glomerular filtration rate. J Nephrol. 2007;20(5):576-85.

14. Parikh CR, Fischer MJ, Estacio R, Schrier RW. Rapid micro-albuminuria screening in type 2 diabetes mellitus: simplified approach with Micral test strips and specific gravity. Nephrol Dial Transplant. 2004;19:1881-5.

15. LambersHeerspink HJ, Brantsma AH, de Zeeuw D, Bakker SJL, de Jong PE, Gansevoort RT, for the PREVEND Study Group. Albuminuria assessed from first-morning-void urine samples versus 24-hour urine collections as a predictor of cardiovascular morbidity and mortality. Am J Epidemiol. 2008; 168:897-905.

16. Noubiap JJN, Naidoo J, Kengne A-P. Diabetic nephropathy in Africa: a systematic review. World J Diabetes. 2015;6(5):759-73.

17. Ngassa PP, Van Zyl DG, Rheeder P. Diabetic nephropathy in a tertiary care clinic in South Africa: a cross-sectional study. JEMDSA 2015; 20(1):67-73.

18. Alebiosu CO, Odusan $\mathrm{O}$, Jaiyesimi A. Morbidity in relation to stage of diabetic nephropathy in type-2 diabetic patients. J Natl Med Assoc. 2003;95:1042-7.

19. Fiseha T, Kassim M, Yemane T. Chronic kidney disease and underdiagnosis of renal insufficiency among diabetic patients attending a hospital in southern Ethiopia. BMC Nephrol. 2014;15:198. https://doi.org/ 10.1186/1471-2369-15-198.

20. Janmohamed MN, Kalluvya SE, Mueller A, Kabangila R, Smart LR, Downs JA, Peck RN. Prevalence of chronic kidney disease in diabetic adult out-patients in Tanzania. BMC Nephrol. 2013;14:183. https://doi. org/10.1186/1471-2369-14-183.

21. Lutale JJK, Thordarson H, Abbas ZG, Vetvik K. Micro-albuminuria among type 1 and type 2 diabetic patients of African origin in Dar Es Salaam, Tanzania. BMC Nephrol. 2007;8:2.

22. Brück K, Stel VS, Gambaro G, Hallan S, Völzke H, Ärnlöv J, Kastarinen M, Guessous I, et al. On behalf of the European CKD burden consortium. CKD 
prevalence varies across the European general population. J Am Soc Nephrol. 2015;27:1-12.

23. Kunal AW, Madhukar C. A case for early screening for diabetic kidney disease. Cardiorenal Med. 2011;65211:235-42.

24. Jaar BG, Khatib R, Plantinga $L$, Boulware LE, Powe NR. Principles of screening for chronic kidney disease. Clin J Am Soc Nephrol. 2008;3(2):601-9.

25. Weis L, Metzger M, Haymann JP, Thervet E, Flamant M, Vrtovsnik F, et al. Renal function can improve at any stage of chronic kidney disease. PLoS One. 2013;8(12):e81835.

26. Howard K, White S, Salkeld G, McDonald S, Craig JC, Chadban S, et al. Costeffectiveness of screening and optimal management for diabetes, hypertension, and chronic kidney disease: a modelled analysis. Value Health. 2010;13(2):196-208.

27. Mallappallil M, Friedman EA, Delano BG, McFarlane SI, Salifu MO. Chronic kidney disease in the elderly: evaluation and management. Clin Pract. 2014; 11(5):525-35.

28. Viswanathan V, Tilak P, Kumpatla S. Risk factors associated with the development of overt nephropathy in type 2 diabetes patients: a 12 years observational study. Indian J Med Res. 2012;136(1):46-53.

29. Adler Al, Stratton IM, Neil HAW, et al. Association of systolic blood pressure with macrovascular and microvascular complications of type 2 diabetes (UKPDS 36): prospective observational study. BMJ. 2000;321(7258):412-9.

30. Ferrannini E, Cushman WC. Diabetes and hypertension: the bad companions. Lancet. 2012;380:601-10.

31. Ruggenenti P, Perna A, Loriga G, et al. Blood-pressure control for renoprotection in patients with non-diabetic chronic renal disease (REIN-2): multicenter, randomized controlled trial. Lancet. 2005;365(9463):939-46.

32. Botdorf J, Chaudhary K, Whaley-Connell A. Hypertension in cardiovascular and kidney disease. Cardio-Renal Med. 2011;1:183-92.

33. Choukem S-P, Dzudie A, Deyahem M, Halle M-P, et al. Comparison of different blood pressure indices for the prediction of prevalent diabetic nephropathy in a sub-Saharan African population with type 2 diabetes. Pan Afr Med J. 2012;11:67.

34. Cooper-DeHoff RM, Gong Y, Handberg EM, et al. Tight blood pressure control and cardiovascular outcomes among hypertensive patients with diabetes and coronary artery disease. JAMA. 2010;304(1):61-8.

35. The ACCORD Study Group. Effects of intensive blood-pressure control in type 2 diabetes mellitus. N Engl J Med. 2010;362:1575-85.

36. Leys D, Deplanque D, Mounier-Vehier C, et al. Stroke prevention: management of modifiable vascular risk factors. J Neurol. 2002;249:507-17.

37. Gæde $\mathrm{P}$, Lund-Andersen $\mathrm{H}$, Parving $\mathrm{H}-\mathrm{H}$, Pedersen $\mathrm{O}$. Effect of a multifactorial intervention on mortality in type 2 diabetes. $\mathrm{N}$ Engl J Med. 2008;358:580-91.

38. Lewis EJ, Hunsicker LG, Clarke WR, et al. Collaborative study group. Renoprotective effect of the angiotensin-receptor antagonist irbesartan in patients with nephropathy due to type 2 diabetes. (IDNT). N Engl J Med. 2001;345:851-60

39. Haller H, Ito S, Izzo JL Jr, Januszewicz A, Katayama S, Menne J, Mimran A, Rabelink TJ, Ritz E, Ruilope LM, Rump LC, Viberti G. Olmesartan for the delay or prevention of micro-albuminuria in type 2 diabetes. N Engl J Med. 2011; 364:907-17.

40. Cooper ME, de Zeeuw D, et al. RENAAL study investigators. Effects of losartan on renal and cardiovascular outcomes in patients with type 2 diabetes and nephropathy. N Engl J Med. 2001;345:861-9.

41. Remuzzi G, Macia M, Ruggenenti P. Prevention and treatment of diabetic renal disease in type 2 diabetes: the BENEDICT study. J Am Soc Nephrol. 2006;17:S90-7.

42. Andrésdóttir $G$, Jensen ML, Carstensen B, Parving HH, Rossing $K$, Hansen TW, Rossing P. Improved survival and renal prognosis of patients with type 2 diabetes and nephropathy with improved control of risk factors. Diabetes Care. 2014;37(6):1660-7.

43. Otieno CF, Vaghela V, Mwendwa FW, Kayima JK, Ogola EN. Cardiovascular risk factors in patients with type 2 diabetes mellitus in Kenya: levels of control attained at the outpatient diabetic clinic of Kenyatta National Hospital, Nairobi. East Afr Med J. 2005;82(12Suppl):184-90.

44. Choukem SP, Kengne AP, Dehayem YM, Simo NL, Mbanya JC. Hypertension in people with diabetes in sub-Saharan Africa: revealing the hidden face of the iceberg. Diabetes Res Clin Pract. 2007;77:293-9.
45. Wilson JMG, Jungner G. Principles and practice of screening for disease. World Health Organization Public Health Papers, No. 34; 1968.http:// whqlibdoc.who.int/php/WHO_PHP_34.pdf.

46. Hallan SI, Dahl K, Oien CM, Grootendorst DC, Aasberg A, Holmen J, Dekker FW. Screening strategies for chronic kidney disease in the general population: follow-up of cross-sectional health survey. BMJ. 2006. https:// doi.org/10.1136/bmj.39001.657755.

47. Kramer $\mathrm{H}$, Molitch ME. Screening for kidney disease in adults with diabetes. Diabetes Care. 2005;28(7):1814-6.

48. Mathew TI, Corso O, Ludlow M, Boyle A, Cass A, Chadban SJ, Joyner B, Shephard M, Usherwood T. Screening for chronic kidney disease in Australia: a pilot study in the community and workplace. Kidney Int Suppl. 2010;77(Suppl 116):S9-S16.

49. Naicker S. Integrated management: chronic kidney disease, diabetes mellitus, hypertension. Afr J Nephrol. 2013;16(1):6-13.

50. George C, Mogueo A, Okpechi I, et al. Chronic kidney disease in lowincome to middle-income countries: the case for increased screening. BMJ Glob Health. 2017;2:e000256. https://doi.org/10.1136/bmjgh-2016-000256.

\section{Publisher's Note}

Springer Nature remains neutral with regard to jurisdictional claims in published maps and institutional affiliations.

\section{Ready to submit your research? Choose BMC and benefit from:}

- fast, convenient online submission

- thorough peer review by experienced researchers in your field

- rapid publication on acceptance

- support for research data, including large and complex data types

- gold Open Access which fosters wider collaboration and increased citations

- maximum visibility for your research: over $100 \mathrm{M}$ website views per year

At BMC, research is always in progress.

Learn more biomedcentral.com/submissions 